Article

\title{
Trace-Level Determination of Polycyclic Aromatic Hydrocarbons in Dairy Products Available in Spanish Supermarkets by Semi-Automated Solid-Phase Extraction and Gas Chromatography-Mass Spectrometry Detection
}

\author{
Laura Palacios Colón, Andrés J. Rascón (D) and Evaristo Ballesteros *(i)
}

check for

updates

Citation: Palacios Colón, L.; Rascón,

A.J.; Ballesteros, E. Trace-Level

Determination of Polycyclic Aromatic Hydrocarbons in Dairy Products Available in Spanish Supermarkets by Semi-Automated Solid-Phase

Extraction and Gas

Chromatography-Mass Spectrometry Detection. Foods 2022, 11, 713. https: //doi.org/10.3390/foods11050713

Received: 11 February 2022 Accepted: 25 February 2022 Published: 28 February 2022

Publisher's Note: MDPI stays neutral with regard to jurisdictional claims in published maps and institutional affiliations.

Copyright: (C) 2022 by the authors. Licensee MDPI, Basel, Switzerland. This article is an open access article distributed under the terms and conditions of the Creative Commons Attribution (CC BY) license (https:// creativecommons.org/licenses/by/ $4.0 /)$.
Department of Physical and Analytical Chemistry, E.P.S of Linares, University of Jaén, 23700 Linares, Spain; lpcolon@ujaen.es (L.P.C.); arascon@ujaen.es (A.J.R.)

* Correspondence: eballes@ujaen.es; Tel.: +34-953-648-560

\begin{abstract}
Polycyclic aromatic hydrocarbons (PAHs) have been classified as priority pollutants by the U.S. Environmental Protection Agency (EPA) and the European Commission on the grounds of their carcinogenic, mutagenic and teratogenic properties. Because of their ubiquity in industrial processes and the environment, PAHs can reach milk and dairy products and, eventually, humans. In this work, a new method was developed to detect and quantify sixteen of the EPA's priority PAHs in commercial milk and dairy products. The method involves liquid-liquid extraction (LLE) followed by semi-automated solid-phase extraction (SPE) to clean up and preconcentrate the analytes prior their detection and quantification by gas chromatography-mass spectrometry (GC-MS). The proposed method provided high precision (relative standard deviation $<11.5 \%$ ), recoveries of $80-107 \%$ and low detection limits (1-200 ng/ $\mathrm{kg}$ ). The method was applied to analyze 30 dairy products, the majority of which contained some PAH at concentrations from 7.1 to $1900 \mathrm{ng} / \mathrm{kg}$. The most-detected analytes were the lighter PAHs (naphthalene, acenaphthylene, fluorene and phenanthrene). None of the samples, however, contained more than four PAHs.
\end{abstract}

Keywords: dairy product composition; priority pollutants; polycyclic aromatic hydrocarbons; health risk; liquid-liquid extraction; continuous solid-phase extraction; gas chromatography-mass spectrometry

\section{Introduction}

Milk and dairy products are among the most nutritionally complete foods available on the market and have historically been essential to the human diet because of their contents of micro- and macronutrients. This has raised increasing concern with their safety [1], which can be compromised by physical, chemical and microbiological contamination during the animal production of milk or, subsequently, during the transport, storage, processing or delivery of milk and dairy products [2]. Especially prominent among the chemical contaminants are polycyclic aromatic hydrocarbons (PAHs). These are ubiquitous environmental pollutants that are formed by the incomplete combustion of organic matter that can reach food through fuel combustion, industrial processes, degasification, petroleum derivative tasks and also through food processing operations, such as drying, smoking or cooking [3]. While low-molecular-weight PAHs can have systemic effects on targets such as the kidney, blood and liver, their high-molecular-weight counterparts are typically carcinogenic or genotoxic [4]. PAH exposure can lead to health effects in the short and long term. In patients with asthma, PAHs can cause pulmonary impairment and thrombosis. In the long term, PAHs can cause different types of cancer (digestive tract, skin and lungs) [5].

PAHs are non-polar compounds whose lipophilicity makes them soluble in lipids, leading to bioaccumulation in foods and in fat tissue from living organisms [6]. PAHs absorbed by inhalation, ingestion or-in small amounts-through the skin are metabolized 
by cytochrome- 450 enzymes to diol-epoxyde derivatives. The binding of these metabolites to glucuronic acid or sulphates makes them water-soluble and facilitates their excretion in urine, bile or milk [7]. Although human urine is the most widely studied matrix as a biomarker for exposure to PAHs, some of them, such as phenanthrene (Phe), pyrene (Pyr) and benzo(a)pyrene (BaP), are preferentially released through fatty solutions, such as milk. Some studies have shown the need to keep the transfer of PAHs to milk under control to avoid their deleterious effects on food safety [8]. This concern has led several authors to quantify them in milk and dairy products [9]. Thus, Chung et al. (2010) found milk samples from Taiwan containing PAHs at concentrations over the range of 4000 to $310,000 \mathrm{ng} / \mathrm{L}$ [10]. Moreover, Lee et al. (2015) found PAHs at levels from 90 to $340 \mathrm{ng} / \mathrm{kg}$ in diverse dairy products from South Korea, with benzo(k)fluoranthene (BkF) present at the highest concentrations [11]. Finally, Fasano et al. (2016) determined the concentration and distribution of $10 \mathrm{PAHs}$ in several plant and animal samples of different origins and found various smoked cheeses from Spain containing PAH's at levels over the range of $20-77,000 \mathrm{ng} / \mathrm{kg}$ [12].

Regulation (EU) No 835/2011 established a maximum allowed level of $1 \mu \mathrm{g} / \mathrm{kg}$ for both $\mathrm{BaP}$ and the sum of $\mathrm{BaP}$, benzo(a)anthracene $(\mathrm{BaA})$, benzo(b)fluoranthene $(\mathrm{BbF})$ and chrysene (Chry) (also known as PAH4) in infant formula and follow-on milk [13]. Moreover, the U.S. Environmental Protection Agency (EPA) has deemed the sixteen PAHs priority pollutants [14]. In addition, the International Agency for Research on Cancer (IARC) has classified PAHs according to carcinogenicity into three groups: (1) definitely carcinogenic $(\mathrm{BaP}) ;(2 \mathrm{~A})$ probably carcinogenic (dibenzo[a,h]anthracene and DBahA) and (2B) possibly carcinogenic to humans (BaA, Chry, naphthalene (Nap), indeno[1,2,3-cd]pyrene (IP), BkF and $\mathrm{BbF}$ ) [15]. A need has, therefore, arisen for accurate, sensitive methods to measure these toxins in foods. Extracting PAHs from milk and dairy products for their determination is a tricky procedure, owing to the high complexity of matrices containing variable amounts of lipids and proteins. Moreover, PAHs are lipophilic and can, thus, easily accumulate in foods (especially in those with high fat contents), which usually require several extraction and cleaning steps before the analytes can be accurately determined [9].

The specific technique to be used to extract PAHs from a food matrix is critically dependent on the nature of the sample. Thus, a cleanup procedure is usually required to remove the coextracted components that potentially interfere with the determination of PAHs in order to avoid matrix effects [9]. Table 1 gathers the recently reported methods for determining PAHs in dairy products. As can be seen, many use a combination of saponification with $\mathrm{KOH}$ in methanol or ethanol and liquid-liquid extraction (LLE) with an organic solvent (usually $n$-hexane or cyclohexane) or a solvent mixture (e.g., ethanol $/ n$-hexane), followed by cleaning up the extract by solid-phase extraction (SPE) with an appropriate sorbent, such as RP-C18 or silica gel [11,12,16-18]. Some methods, however, omit one of the previous steps $[10,19,20]$. Moreover, some authors have used alternative techniques including solid-phase microextraction [21], in-tube solid-phase microextraction [22], direct immersion solid-phase microextraction [23], ionic liquid liquid-phase micro-extraction [24], Soxhlet plus gel permeation chromatography [25], magnetic solid-phase extraction [20] and QuEChERS [26] to prepare dairy samples.

Gas chromatography (GC) and high-performance liquid chromatography (HPLC) are the two main instrumental choices for the identification and quantification of PAHs [2,9]. Most of the methods in Table 1 use GC coupled to single-quadrupole mass spectrometry (GC-MS) $[10,11,19,21,23,27,28]$ or triple-quadrupole mass spectrometry [25,26], although GC with flame ionization detection is also frequently used instead [27]. On the other hand, photodiode array [24], fluorescence [7,12,16,18,20,29-32] and mass spectrometry detectors [17] are the main choices for determining PAHs by HPLC. Because some PAHs are not fluorescent, mass spectrometers usually provide more accurate and robust results than fluorescence detectors [3].

The aim of this work is the development of an analytical methodology to detect the EPA's 16 PAH priority pollutants in milk and dairy products. First, continuous solid- 
phase extraction (SPE) was used in combination with liquid-liquid extraction (LLE) for the extraction and cleanup of the analytes. Then, the operational variables potentially influencing the performance in the analysis of milk and dairy products were optimized with to the goal of avoiding matrix effects and maximizing sensitivity, selectivity, precision and accuracy. The variables influencing the determination of the analytes by GC coupled to MS in the electron impact (EI) mode were also optimized. The ensuing method was used to quantify PAHs in different types of milk (cow's, goat's and sheep's whole, semi-skimmed and skimmed milk) and dairy products (yogurt, milkshakes, cream, custard, cheese, butter and margarine).

Table 1. Selected studies for the presence of PAHs in milk and dairy products.

\begin{tabular}{|c|c|c|c|c|c|c|}
\hline Samples & $\begin{array}{l}\text { Sample } \\
\text { Treatment }{ }^{\text {a }}\end{array}$ & Technique $^{\mathrm{a}}$ & $\begin{array}{l}\text { Analytical } \\
\text { Characteristics }^{\text {a }}\end{array}$ & Analytes $^{a}$ & Concentration Found in Real Samples ${ }^{b}$ & References \\
\hline Milk & $\mathrm{LLE}+\mathrm{SPE}$ & GC-MS & R: $80-120 \%$ & 16 PAHs & $\begin{array}{l}\text { Nap: 67,000-310,000 ng/L; Ap: 5000-12,000 } \\
\text { ng/L; Ac: 58,000-98,000 ng/L; F: 5000-24,000 } \\
\text { ng/L; Phe: 21,000-86,000 ng/L; Ant: 18,000 } \\
\text { ng/L; Flu: 6000-13,000 ng/L; Pyr: 5000-135,000 } \\
\text { ng/L; BaA: 8000-19,000 ng/L; Chry: } \\
\text { 19,000-34,000 ng/L; BbF: 6000 ng/L; BkF: } 4000 \\
\text { ng/L; BaP: 7000-9000 ng/L }\end{array}$ & [10] \\
\hline $\begin{array}{l}\text { Milk and } \\
\text { dairy } \\
\text { product }\end{array}$ & $\begin{array}{l}\text { Saponification } \\
+ \text { LLE + SPE }\end{array}$ & GC-MS & $\begin{array}{l}\text { LOD: } 40-200 \\
\text { ng/kg } \\
\text { RSD: } 6.8-13.3 \% \\
\text { R: } 87-103 \%\end{array}$ & 8 PAHs & $\begin{array}{l}\text { Cheese: BaA: } 280 \text { ng/kg, BkF: } 90 \text { ng/kg, BbF: } 340 \\
\text { ng/kg, BaP: } 240 \text { ng/kg, BP: } 220 \text { ng/kg, DBahA: } \\
210 \text { ng/kg }\end{array}$ & {$[11]$} \\
\hline Cheese & $\begin{array}{l}\text { Saponification } \\
+ \text { LLE + SPE }\end{array}$ & HPLC-FLD & $\begin{array}{l}\text { LOD: } 250-1500 \\
\text { ng/kg } \\
\text { RSD: } 3.7-7.4 \% \\
\text { R: } 66-107 \%\end{array}$ & 10 PAHs & $\begin{array}{l}\text { Flu: 17,000-77,000 ng/kg; Phe: 44,000-47,000 } \\
\text { ng/kg; BaA: 30-14,000 ng/kg; Chry: 30-8800 } \\
\text { ng/kg; BbF: 1700-2900 ng/kg; BkF: 20-1600 } \\
\text { ng/kg; BaP: 40-5400 ng/kg; B(ghi)P: 90-100 } \\
\text { ng/kg; B(ghi)P: 1600-4200 ng/kg; IP: 1600-2800 } \\
\text { ng/kg }\end{array}$ & [12] \\
\hline Cheese & $\begin{array}{l}\text { Saponification } \\
+ \text { LLE + SPE }\end{array}$ & HPLC-FLD & $\begin{array}{l}\text { LOD: } 40-90 \\
\text { ng/kg } \\
\text { RSD: } 6.5-12.5 \% \\
\text { R: } 73-93 \%\end{array}$ & 9 PAHs & $\begin{array}{l}\text { Nap: } 240-7980 \text { ng/kg; Ac: 100-3060 ng/kg; Ant: } \\
\text { 210-820 ng/kg; Pyr: 90-1130 ng/kg; BaA: 80-90 } \\
\text { ng/kg; BkF: 60-380 ng/kg; BaP: 60-690 ng/kg; } \\
\text { DBahA: 60-730 ng/kg; BP: 70-270 ng/kg }\end{array}$ & [16] \\
\hline $\begin{array}{l}\text { Heat- } \\
\text { treated } \\
\text { milk }\end{array}$ & $\begin{array}{l}\text { Saponification } \\
+ \text { LLE + SPE }\end{array}$ & $\begin{array}{l}\text { HPLC-FLD } \\
\text { HPLC-MS }\end{array}$ & $\begin{array}{l}\text { LOQ: } 12-201 \\
\text { ng/kg } \\
\text { RSD: } 0.8-10.4 \% \\
\text { R: } 89-94 \%\end{array}$ & 8 PAHs & $\begin{array}{l}\text { Phe:1425-1831 ng/kg; Ant:1296-2473 ng/kg; Pyr: } \\
\text { 1351-2132 ng/kg; BaA: 813-1072 ng/kg; Chry: } \\
\text { 104-261 ng/kg; BkF: 67 ng/kg; BaP: 35-270 } \\
\text { ng/kg; BP: 13-39 ng/kg }\end{array}$ & [17] \\
\hline Milk & $\begin{array}{l}\text { Saponification } \\
+ \text { LLE + SPE }\end{array}$ & HPLC-FLD & $\begin{array}{l}\text { LOD: } 5-110 \\
\text { ng/kg } \\
\text { RSD <9\% } \\
\text { R: } 65-89 \%\end{array}$ & 14 PAHs & $\begin{array}{l}\text { Ap: } 210 \text { ng/kg; Flu: } 1690 \text { ng/kg; Phe: } 720 \text { ng/kg; } \\
\text { Ant: 17,420 ng/kg; F: 25,860 ng/kg; Pyr: } 250 \\
\text { ng/kg; BaA: } 1280 \text { ng/kg; Chry: 770 ng/kg; BbF: } \\
\text { 520 ng/kg; BkF: } 2450 \text { ng/kg; BaP: } 540 \text { ng/kg; } \\
\text { DBahA: } 460 \text { ng/kg; BP:270 ng/kg; IP: } 240 \text { ng/kg }\end{array}$ & [18] \\
\hline $\begin{array}{l}\text { Milk and } \\
\text { milk } \\
\text { powder }\end{array}$ & $\mathrm{LLE}+\mathrm{SPE}$ & GC-MS & $\begin{array}{l}\text { LOD: } 40-75 \\
\text { ng/kg } \\
\text { RSD: } 3.2-10.1 \% \\
\text { R: } 86-100 \%\end{array}$ & 16 PAHs & $\begin{array}{l}\text { Nap: 20-40 ng/kg; Ap: 20-70 ng/kg; Ac: 20-30 } \\
\text { ng/kg; F: 20-80 ng/kg; Phe: 20-110 ng/kg; Ant: } \\
\text { 20-90 ng/kg; Flu: 30-250 ng/kg; Pyr: 120-500 } \\
\text { ng/kg; BaA: 30-110 ng/kg; Chry: 70-300 ng/kg; } \\
\text { BbF: 200-520 ng/kg; BkF: 20-50 ng/kg; BaP: } \\
\text { 20-40 ng/kg; } \\
\text { IP: } 20-70 \text { ng/kg; DBahA: 20-40 ng/kg; BP: } \\
\text { 80-350 ng/kg }\end{array}$ & [19] \\
\hline $\begin{array}{l}\text { Skim } \\
\text { milk }\end{array}$ & Magnetic SPE & HPLC-FLD & $\begin{array}{l}\text { LOD: } 0.2-0.6 \\
\text { ng/L } \\
\text { RSD:1-9\% } \\
\text { R: } 429-115 \%\end{array}$ & 6 PAHs & nd & [20] \\
\hline Milk & SMPE & GC-MS & $\begin{array}{l}\text { LOD: } 100-800 \\
\text { ng/kg } \\
\text { R: } 75-108 \%\end{array}$ & 6 PAHs & $\begin{array}{l}\text { Phe: } 4100 \text { ng/kg; Ant: } 900 \text { ng/kg; Flu: } 800 \\
\text { ng/kg; Pyr } 200 \text { ng/kg }\end{array}$ & [21] \\
\hline Milk & IT-SPME & HPLC-FLD & $\begin{array}{l}\text { LOD: } 0.10-2.36 \\
\text { ng/L } \\
\text { RSD }<11 \% \\
\text { R: } 76-119 \%\end{array}$ & 10 PAHs & Flu: $0.84-1.32 \mathrm{ng} / \mathrm{L}$; Chry: $1.51 \mathrm{ng} / \mathrm{L}$ & [22] \\
\hline
\end{tabular}


Table 1. Cont.

\begin{tabular}{|c|c|c|c|c|c|c|}
\hline Samples & $\begin{array}{l}\text { Sample } \\
\text { Treatment }^{\text {a }}\end{array}$ & Technique $^{\text {a }}$ & $\begin{array}{l}\text { Analytical } \\
\text { Characteristics }{ }^{\text {a }}\end{array}$ & Analytes $^{a}$ & Concentration Found in Real Samples ${ }^{b}$ & References \\
\hline $\begin{array}{l}\text { Milk and } \\
\text { dairy } \\
\text { product }\end{array}$ & DI-SPME & GC-MS & $\begin{array}{l}\text { LOD: } 30-1560 \\
\text { ng/L } \\
\text { RSD: } 4.9-19.6 \% \\
\text { R: } 88-112 \%\end{array}$ & 16 PAHs & $\begin{array}{l}\text { Fat milk: Flu: } 830-1040 \text { ng/L; Pyr: 630-1120 } \\
\text { ng/L }\end{array}$ & [23] \\
\hline Milk & $\begin{array}{l}\text { IL-HF- } \\
\text { LPME }\end{array}$ & HPLC-DAD & $\begin{array}{l}\text { LOD: } 140-710 \\
\text { ng/L } \\
\text { RSD } 1.2-3.3 \% \\
\text { R: } 94-103 \%\end{array}$ & 3 PAHs & nd & [24] \\
\hline $\begin{array}{l}\text { Milk and } \\
\text { dairy } \\
\text { products }\end{array}$ & $\begin{array}{l}\text { Soxhlet + } \\
\text { GPC }\end{array}$ & CG-MS/MS & - & 16 PHAs & $\begin{array}{l}\text { ¿PHA16; Milk: 147,700 ng/kg; Cheese: 76,600 } \\
\text { ng/kg; Yogurt: 12,800 ng/kg; Butter: 7800 ng/kg }\end{array}$ & [25] \\
\hline Milk & QuEChERS & GC-MS/MS & $\begin{array}{l}\text { LOD: } 80-150 \\
\text { ng/kg } \\
\text { RSD }<6 \% \\
\text { R: } 63-105 \%\end{array}$ & 16 PHAs & $\begin{array}{l}\text { Nap: 90-1180 ng/kg; Ap: 80-120 ng/kg; Ac: } \\
\text { 60-680 ng/kg; F: 120-1620 ng/kg; Phe: } 240-920 \\
\text { ng/kg; Ant: 510-3850 ng/kg; Flu: 100-880 } \\
\text { ng/kg; Pyr: 80-830 ng/kg; BaA: 490-1060 ng/kg; } \\
\text { Chry: 220-770 ng/kg; BkF: 420-800 ng/kg; BbF: } \\
\text { 230-880 ng/kg; BaP: 370-830 ng/kg; IP: 450-1690 } \\
\text { ng/kg; DBahA: 240-1160 ng/kg; BP: 240-950 } \\
\text { ng/kg }\end{array}$ & [26] \\
\hline Milk & $\begin{array}{l}\text { Saponification } \\
\text { + LLE }\end{array}$ & GC-FID & $\begin{array}{l}\text { LOD: } 50-450 \\
\text { ng/kg } \\
\text { RSD }<7.8 \% \\
\text { R: } 79-99 \%\end{array}$ & 16 PAHs & ¿PHA16: 15,600-171,180 ng/kg & [27] \\
\hline $\begin{array}{l}\text { Smoked } \\
\text { cheeses }\end{array}$ & Soxhlet + SPE & GC-MS & $\begin{array}{l}\text { LOQ: } 900-20,000 \\
\text { ng/kg }\end{array}$ & 16 PAHS & $\begin{array}{l}\text { Nap: 20,000-1,200,000 ng/kg; Ap: 2700-1,200,000 } \\
\text { ng/kg; Ac: 1300-38,000 ng/kg; F: 6200-400,000 } \\
\text { ng/kg; Phe: 8500-790,000 ng/kg; Ant: 1600 } \\
\text { ng/kg; Flu: 2700-94,000 ng/kg; Pyr: } 1600-67,000 \\
\text { ng/kg; BaA: 1500-9700 ng/kg; Chry: } 1600-7300 \\
\text { ng/kg; BbF: } 970-1100 \text { ng/kg; BkF: } 1200-2300 \\
\text { ng/kg; BaP: 850-4500 ng/kg }\end{array}$ & [28] \\
\hline Yogurt & $\begin{array}{l}\text { Saponification } \\
+ \text { LLE }\end{array}$ & HPLC-FLD & $\begin{array}{l}\text { RSD: } 2-20 \% \\
\text { R:33-130\% }\end{array}$ & 13 PHAs & $\begin{array}{l}\text { Yogurt whole: Ac: } 1850 \text { ng/kg; F: } 1400 \mathrm{~g} / \mathrm{kg} \text {; Phe: } \\
4700 \mathrm{ng} / \mathrm{kg} \text {; Ant: } 150 \mathrm{ng} / \mathrm{kg} \text {; Flu: } 1000 \mathrm{ng} / \mathrm{kg} ; \\
\text { Pyr: } 600 \mathrm{ng} / \mathrm{kg} \text {; Chry: } 50 \mathrm{ng} / \mathrm{kg} \text {; DBahA: } 30 \\
\text { ng/kg; } \\
\text { Yogurt skimmed: Ac: } 650 \mathrm{ng} / \mathrm{kg} \text {; F: } 770 \mathrm{ng} / \mathrm{kg} ; \\
\text { Phe: } 2420 \mathrm{ng} / \mathrm{kg} \text {; Ant: } 80 \mathrm{ng} / \mathrm{kg} \text { Flu: } 630 \mathrm{ng} / \mathrm{kg} \text {; } \\
\text { Pyr: } 320 \mathrm{ng} / \mathrm{kg} \text {; Chry: } 30 \mathrm{ng} / \mathrm{kg} \text {; DBahA: } 40 \\
\mathrm{ng} / \mathrm{kg}\end{array}$ & [29] \\
\hline Yogurt & $\begin{array}{l}\text { Saponification } \\
+ \text { LLE }\end{array}$ & HPLC-FLD & $\begin{array}{l}\text { LOD: } 50-70 \\
\text { ng/kg } \\
\text { RSD: } 5.9-16.9 \% \\
\text { R: } 84-106 \%\end{array}$ & 4 PAHs & BaA: 90 ng/kg; Chry: 310 ng/kg; BaP: 160 ng/kg & [31] \\
\hline $\begin{array}{l}\text { Milk and } \\
\text { dairy } \\
\text { product }\end{array}$ & $\mathrm{LLE}+\mathrm{SPE}$ & GC-MS & $\begin{array}{l}\text { LOD: } 1-200 \\
\text { ng/kg } \\
\text { RSD: } 5.0-11.3 \% \\
\text { R: } 80-107 \%\end{array}$ & 16 PHAs & $\begin{array}{l}\text { Nap: } 260-1900 \mathrm{ng} / \mathrm{kg} \text {; Ac: } 7.1-510 \mathrm{ng} / \mathrm{kg} \text {; } \\
\text { F:30-520 ng/kg; } \\
\text { Phe: } 88 \mathrm{ng} / \mathrm{kg}\end{array}$ & $\begin{array}{l}\text { This } \\
\text { work }\end{array}$ \\
\hline
\end{tabular}

a DI-SMPE: direct immersion solid-phase microextraction; GC-MS: gas chromatography coupled to singlequadrupole mass spectrometry; GC-MS/MS: gas chromatography coupled to triple-quadrupole mass spectrometry; GPC: gel permeation chromatography; HPLC-DAD: high-performance liquid chromatography-photodiode array detection; HPLC-FLD: high-performance liquid chromatography-fluorescence detection; HPLC-MS: high-performance liquid chromatography-mass spectrometry; IL-HF-LPME: ionic liquid liquid-phase microextraction; IT-SPME: in-tube solid-phase microextraction; LLE: liquid-liquid extraction; LOD: detection limit; LOQ: quantification limit; QuEChERS: quick, easy, cheap, effective, rugged and safe; R: recovery; SPE: solid-phase extraction; SPME: solid-phase micro-extraction; RSD relative standard deviation. ${ }^{\mathrm{b}}$ Ac: acenaphthene; Ap: acenaphthylene; Ant: anthracene; BaA: benzo(a)anthracene; BaP: benzo(a)pyrene; BbF: benzo(b)fluoranthene; $\mathrm{BP}$ : benzo[g.h.i]perylene; BkF: benzo(k)fluoranthene; Chry: chrysene; DBahA: dibenzo[a.h]anthracene; F: fluorine; Flu: fluoranthene; IP: indeno[1.2.3-cd]perylene; Nap: naphthalene; Phe: phenanthrene; Pyr: pyrene; ¿PAH16: sum of the 16 PAHs; nd: not detected. 


\section{Materials and Methods}

\subsection{Chemical and Solvents}

Analytical standards for the EPA's sixteen priority PAHs (viz., Nap, acenapthylene (Ap), acenaphthene (Ac), fluorene (F), Chry, BaA, fluoranthene (Flu), Pyr, BkF, BbF, BaP, Phe, anthracene (Ant), Benzo[ghi]perylene (BP), DBahA and IP) were purchased in the highest available purity from Dr. Ehrenstofer (Augsburg, Germany), Across (Geel, Belgium) or Fluka (St. Louis, MO, USA). The internal standard (IS), triphenylphosphate, was supplied by Fluka (St. Louis, MO, USA). Reversed-phase silica with octadecyl functional groups (RP-C18) was obtained from Supelco (Madrid, Spain). Methanol (MeOH), ethanol (EtOH), ethyl acetate, $n$-hexane, acetone, acetonitrile (ACN), N,N-dimethylformamide (DMF) and 2-propanol were purchased from Merck (Darmstadt, Germany). Finally, ultrapure water was supplied by a Milli-Q system from Millipore.

All solutions were prepared individually by dissolving each analyte at $5 \mathrm{~g} / \mathrm{L}$ in acetone. The stock solutions were stored at $4{ }^{\circ} \mathrm{C}$ in the dark to avoid volatilization and photodegradation. Mixed standards containing all analytes at $1 \mathrm{mg} / \mathrm{L}$ in acetone were prepared by appropriate dilution on a daily basis [3]. The eluent used was 2-propanol containing $100 \mu \mathrm{g} / \mathrm{L}$ IS, also prepared daily.

\subsection{Dairy Samples}

Eleven samples of different milk brands were purchased, including whole $(3.6 \%$ fat content), semi-skimmed (1.6\%) and skimmed (0.3\%) cow's, goat's (3.9\%) and sheep's (6.5\%) milk. On the other hand, the seventeen samples of dairy products purchased included yogurt $(2.6-5.4 \%$ fat content), milkshakes $(1.0-1.5 \%)$, cream $(18 \%)$, custard $(2.4-3.9 \%)$, cheese (12.1-13.1\%), butter (81-82\%) and margarine (60\%). All samples were bought in Spanish supermarkets and stored in the dark at $4{ }^{\circ} \mathrm{C}$ until analysis. Each sample was analyzed in triplicate.

\subsection{Equipemnts}

Gas chromatography-mass spectrometry analyses were performed on a Focus gas chromatograph (Thermo Electron SA, Madrid, Spain) coupled to a DSQ II quadrupole mass spectrometer using an electronic ionization source (EI) and an AL/AS 3000 AutoSampler. The chromatograph was equipped with an HP-5MS capillary column $(30 \mathrm{~m}, 0.25 \mathrm{~mm}$ i.d., $0.25 \mu \mathrm{m}$ film thickness) from J\&W (Folson, CA, USA). Helium (99.999\% pure) at a constant flow rate of $1.0 \mathrm{~mL} / \mathrm{min}$ was used as the carrier gas. The oven temperature was initially set at $70{ }^{\circ} \mathrm{C}$, which was held for $2 \mathrm{~min}$ and followed by a $10{ }^{\circ} \mathrm{C} / \mathrm{min}$ ramp to $240{ }^{\circ} \mathrm{C}$ and another at $15{ }^{\circ} \mathrm{C} / \mathrm{min}$ to $290^{\circ} \mathrm{C}$, the final temperature being held for $12 \mathrm{~min}$. The temperature of the transfer line was set at $280^{\circ} \mathrm{C}$, the ion source, which was operated in the EI mode $(70 \mathrm{eV})$, was set at $200^{\circ} \mathrm{C}$ and solvent delay was set at $5 \mathrm{~min}$. The injector was used in splitless mode at $300{ }^{\circ} \mathrm{C}$ with an injected volume of $1 \mu \mathrm{L}$. Detection was performed in selected ion monitoring mode (SIM) for at least three characteristic ions for each analyte. The $m / z$ values for each target compound are listed in Table 2.

A Centrofriger BL-II centrifuge from JP Selecta (Barcelona, Spain) was used. The continuous SPE system consisted of a peristaltic pump (Gilson, Villiers-le-Bel, France) and two Rheodyne 5041 injection valves (Cotati, CA, USA). The tubes were made of poly(vinyl chloride), and PTFE columns were custom-packed with various sorbents. All columns were conditioned by passing $1 \mathrm{~mL}$ of acetonitrile, $1 \mathrm{~mL}$ of methanol and $10 \mathrm{~mL}$ of ultrapure water in this sequence.

\subsection{Extraction of PHAs}

Figure 1 depicts the extraction/cleanup procedure. Samples were defrosted-and crushed, if solid-in $50 \mathrm{~mL}$ polypropylene centrifuge tubes. Next, $1 \mathrm{~g}$ of each of the milk, yogurt, milkshake, cream, custard or cheese samples were placed into the $50 \mathrm{~mL}$ polypropylene centrifuge tubes and then $6 \mathrm{~mL}$ of a $(9: 1 \mathrm{v} / \mathrm{v}) \mathrm{DMF}: \mathrm{H}_{2} \mathrm{O}$ solution was added for the liquid-liquid extraction procedure. Then, $4 \mathrm{~mL}$ of ethanol was added, and the tube 
was vortexed for $2 \mathrm{~min}$. By contrast, the butter and margarine samples were prepared as follows: First, $0.5 \mathrm{~g}$ was weighed into a $50 \mathrm{~mL}$ polypropylene centrifuge tube, then $6 \mathrm{~mL}$ of $(9: 1 \mathrm{v} / \mathrm{v})$ DMF: $\mathrm{H}_{2} \mathrm{O}$ solution was added for LLE and then $5 \mathrm{~mL}$ of $n$-hexane was added for vortexing (2 min). Next, all milk and dairy samples were centrifuged at $2150 \times g(5000 \mathrm{rpm})$ at $4{ }^{\circ} \mathrm{C}$ for $15 \mathrm{~min}$ to precipitate the unsaponifiable fats and proteins from the organic layer. This resulted in two separated phases, the extractant was then collected in a new tube.

Table 2. Analytical characteristics of the determination of PAHs in milk and dairy products by the proposed method.

\begin{tabular}{|c|c|c|c|c|c|c|c|c|c|c|c|c|c|c|c|c|c|}
\hline \multirow{2}{*}{ Compound } & & \multicolumn{6}{|c|}{ Milk Sample } & \multicolumn{5}{|c|}{ Butter Sample } & & & \multicolumn{3}{|c|}{${ }^{\mathrm{c}} m / z$} \\
\hline & & \multicolumn{2}{|r|}{$\begin{array}{l}{ }^{\text {a }} \text { LOD } \\
\text { (ng/kg) }\end{array}$} & ${ }^{b} \mathbf{r}$ & \multicolumn{3}{|c|}{$\begin{array}{c}\text { Linear Range } \\
\text { (ng/kg) }\end{array}$} & \multicolumn{2}{|l|}{$\begin{array}{l}{ }^{\text {a }} \text { LOD } \\
\text { (ng/kg) }\end{array}$} & ${ }^{b} \mathbf{r}$ & \multicolumn{2}{|c|}{$\begin{array}{l}\text { Linear } \\
\text { Range } \\
\text { (ng/kg) }\end{array}$} & \multicolumn{2}{|c|}{$t_{R}$} & \multicolumn{3}{|c|}{$\begin{array}{l}\text { Additional } \\
\text { Ions }\end{array}$} \\
\hline \multicolumn{3}{|c|}{ Naphthalene (Nap) } & 1 & 0.9932 & \multicolumn{3}{|c|}{$4-20,000$} & 2 & \multicolumn{2}{|c|}{0.9991} & \multicolumn{2}{|c|}{$7-40,000$} & \multicolumn{2}{|c|}{9.22} & 128 & \multirow{2}{*}{\multicolumn{2}{|c|}{$\begin{array}{c}102,126 \\
151,153 \\
154\end{array}$}} \\
\hline \multicolumn{3}{|c|}{ Acenaphthylene (Ap) } & 1 & 0.9955 & \multicolumn{3}{|c|}{$4-20,000$} & 2 & \multicolumn{2}{|c|}{0.9942} & \multicolumn{2}{|c|}{$7-40,000$} & 12 & & 152 & & \\
\hline Acenaphthe & (Ac) & & 1 & 0.9943 & & $4-20,000$ & & 2 & & 956 & $7-4$ &, 000 & 13 & & 154 & 152 & 153 \\
\hline Fluorene $(\mathrm{F})$ & & & 2 & 0.9941 & & $7-20,000$ & & 5 & & 981 & $16-4$ & 0,000 & 14 & & 166 & 165 & 167 \\
\hline Phenanthrer & (Phe) & & 1 & 0.9955 & & $4-20,000$ & & 2 & & 935 & $7-4$ & , 000 & 16 & & 178 & 176 & 179 \\
\hline Anthracene & nt) & & 8 & 0.9956 & & $26-20,000$ & & 17 & & 967 & $55-4$ & 0,000 & 17 & & 178 & 159 & 176 \\
\hline Fluoranthen & (Flu) & & 10 & 0.9951 & & $35-20,000$ & & 19 & & 998 & $60-4$ & 0,000 & 19 & & 202 & 201 & 203 \\
\hline Pyrene (Pyr & & & 10 & 0.9954 & & $35-20,000$ & & 20 & & 961 & $65-4$ & 0,000 & 20 & & 202 & 200 & 203 \\
\hline Benzo(a)ant & ancen & & 25 & 0.9982 & & $85-20,000$ & & 48 & & 989 & $160-$ & 0,000 & 22 & & 228 & 226 & 229 \\
\hline Chrysene (C & & & 25 & 0.9979 & & $85-20,000$ & & 50 & & 936 & 170 & 0,000 & 22 & & 228 & 114 & 226 \\
\hline Benzo(b)fluc & anthen & & 25 & 0.9957 & & $85-20,000$ & & 50 & & 945 & $170-$ & 0,000 & 25 & & 252 & & $\begin{array}{l}249, \\
0\end{array}$ \\
\hline Benzo(k)flu & anthen & & 25 & 0.9951 & & $85-20,000$ & & 49 & & 971 & $160-$ & 0,000 & 25 & & 252 & 249 & 250 \\
\hline Benzo(a)pyr & e (BaI & & 25 & 0.9966 & & $85-20,000$ & & 50 & & 950 & $175-$ & 0,000 & 26 & & 252 & 129 & 253 \\
\hline $\begin{array}{l}\text { Dibenzo[a.h } \\
\text { (DBahA) }\end{array}$ & thrac & & 100 & 0.9938 & & $350-20,000$ & & 190 & & 949 & $620-$ & 0,000 & 30 & & 278 & 139 & 279 \\
\hline Benzo[ghi]p & ylene & & 100 & 0.9984 & & $350-20,000$ & & 200 & & 935 & $640-$ & 0,000 & 31 & & 276 & 272 & 277 \\
\hline Indeno[1.2.3 & d]pyr & & 100 & 0.9955 & & $350-20,000$ & & 190 & & 973 & $630-$ & 0,000 & 32 & & 276 & 138 & 277 \\
\hline & & & & & & & SD ( & & & & & & & & & & \\
\hline Compound & & & & & But & tter & & Cheese & & & stard & & & Milk & hake & Marg & arine \\
\hline compouna & WD & BD & WD & BD & WD & BD & WD & & & WL & BD & WD & $\mathrm{BD}$ & WD & $\mathrm{BD}$ & WD & BD \\
\hline Nap & 8.6 & 10.5 & 8.5 & 10.3 & 8.2 & 9.8 & 7.0 & & & 8.7 & 10.1 & 7.9 & 9.3 & 9.0 & 10.1 & 7.5 & 9.2 \\
\hline Ap & 7.6 & 9.3 & 7.9 & 9.4 & 9.8 & 11.0 & 8.7 & & & 8.6 & 9.6 & 9.2 & 8.4 & 10.0 & 10.5 & 8.0 & 9.5 \\
\hline Ac & 8.9 & 10.5 & 9.5 & 10.9 & 7.9 & 10.8 & 8.6 & & & 9.1 & 10.5 & 5.0 & 8.9 & 8.7 & 9.3 & 8.1 & 10.0 \\
\hline $\mathrm{F}$ & 8.9 & 9.8 & 8.9 & 11.0 & 8.9 & 10.2 & 5.9 & & & 7.9 & 8.8 & 7.1 & 10.6 & 8.9 & 10.0 & 6.1 & 8.8 \\
\hline Phe & 7.9 & 10.6 & 9.6 & 11.3 & 8.9 & 10.7 & 9.1 & & & 5.9 & 7.9 & 7.5 & 9.9 & 8.0 & 11.3 & 9.0 & 10.1 \\
\hline Ant & 8.1 & 9.4 & 9.0 & 10.9 & 7.9 & 10.7 & 10.1 & & & 8.6 & 10.2 & 8.5 & 10.1 & 7.9 & 9.6 & 8.5 & 11.3 \\
\hline Flu & 8.0 & 8.8 & 9.1 & 10.0 & 5.9 & 8.8 & 8.1 & & & 7.9 & 11.0 & 9.1 & 10.9 & 8.9 & 9.8 & 8.6 & 9.7 \\
\hline Pyr & 9.2 & 11.0 & 10.0 & 11.3 & 6.2 & 8.5 & 8.9 & & & 8.9 & 11.1 & 8.2 & 10.1 & 7.5 & 9.9 & 7.5 & 9.1 \\
\hline $\mathrm{BaA}$ & 5.0 & 6.9 & 8.7 & 9.7 & 8.7 & 10.3 & 7.4 & & & 5.1 & 8.9 & 10.1 & 10.9 & 9.5 & 10.5 & 7.6 & 10.2 \\
\hline Chry & 7.1 & 8.8 & 8.9 & 11.2 & 8.6 & 10.8 & 8.9 & & & 5.9 & 10.6 & 7.9 & 8.1 & 8.9 & 9.3 & 9.1 & 10.4 \\
\hline $\mathrm{BbF}$ & 7.5 & 8.9 & 7.9 & 10.3 & 7.9 & 11.5 & 8.3 & & & 7.1 & 9.9 & 8.9 & 9.9 & 9.6 & 10.5 & 8.5 & 9.6 \\
\hline $\mathrm{BkF}$ & 8.5 & 10.6 & 8.6 & 9.7 & 8.9 & 10.1 & 8.5 & & & 8.9 & 10.1 & 9.8 & 10.9 & 9.5 & 9.8 & 8.0 & 9.8 \\
\hline $\mathrm{BaP}$ & 9.1 & 9.9 & 8.8 & 11.0 & 8.4 & 10.6 & 7.9 & & & 6.5 & 9.5 & 10.2 & 10.5 & 7.0 & 10.6 & 6.3 & 9.6 \\
\hline DBahA & 8.9 & 10.1 & 8.9 & 11.2 & 9.0 & 10.1 & 8.6 & & & 6.6 & 9.9 & 9.9 & 10.7 & 8.7 & 9.5 & 7.2 & 9.0 \\
\hline BP & 8.6 & 9.6 & 9.6 & 10.4 & 7.6 & 8.9 & 7.9 & & & 6.7 & 7.9 & 8.7 & 10.6 & 8.9 & 9.8 & 7.4 & 9.8 \\
\hline IP & 7.9 & 8.3 & 7.9 & 10.7 & 8.6 & 10.9 & 7.8 & & & 7.8 & 8.7 & 9.9 & 10.3 & 5.9 & 8.9 & 8.6 & 10.1 \\
\hline
\end{tabular}

${ }^{a}$ LOD: detection limit; ${ }^{b} \mathrm{r}$ : correlation coefficient; $\mathrm{t}_{\mathrm{R}}$ : retention time; ${ }^{\mathrm{c}} \mathrm{m} / \mathrm{z}$ mass/charge ratio; $\left[\mathrm{M}^{+}\right]$: ionized mass; the base peaks used for quantification are boldfaced; $m / z$ for IS (triphenylphosphate): $170,325,326$; ${ }^{\mathrm{d}} \mathrm{RSD}$. relative standard deviation $(n=12)$, values obtained for samples fortified with $500 \mathrm{ng} / \mathrm{kg}$, except for butter and margarine, which was $1000 \mathrm{ng} / \mathrm{kg}$; WD: within-day; BD: between-day. 


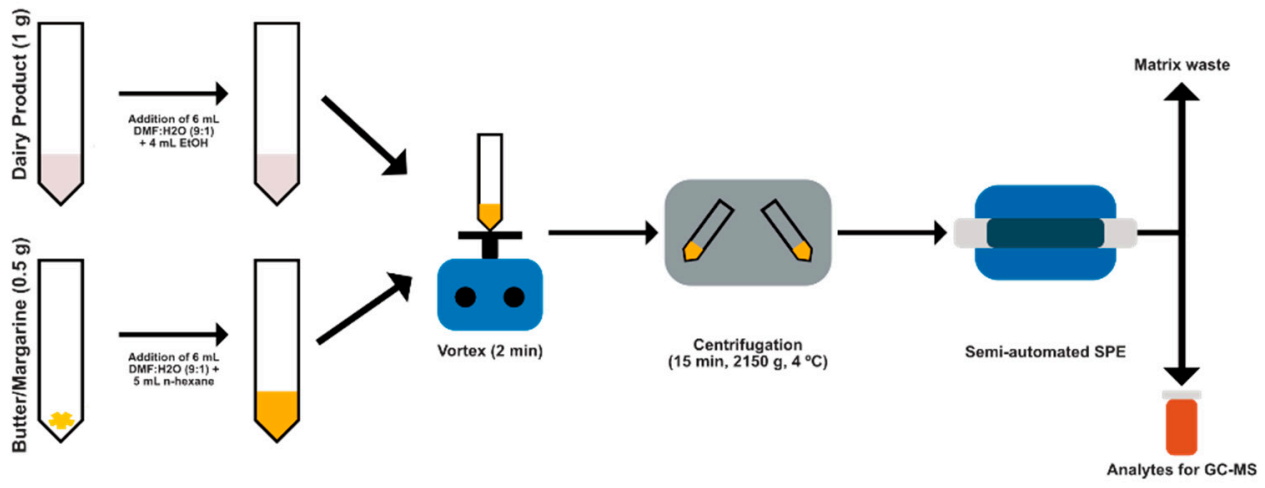

Figure 1. Procedure for determining polycyclic aromatic hydrocarbons in milk and dairy products.

The resulting aqueous extracts were diluted to $50 \mathrm{~mL}$ with ultrapure water and passed at a constant flow rate of $5.0 \mathrm{~mL} / \mathrm{min}$ through the continuous SPE system, equipped with a sorbent column packed with $60 \mathrm{mg}$ of RP-C18 placed in the loop of the injection valve $\left(\mathrm{IV}_{1}\right)$, (Figure S1, Supporting Information). As a result, the analytes were retained by the sorbent, and the matrix was discharged to waste. Then, the column was dried with an air stream at $5.0 \mathrm{~mL} / \mathrm{min}$ in both directions for $2 \mathrm{~min}$, and the other valve $\left(\mathrm{IV}_{2}\right)$ was switched to elute the analytes with $350 \mu \mathrm{L}$ of a 2-propanol solution containing $100 \mu \mathrm{g} / \mathrm{L}$ triphenylphosphate (IS) that was held in the loop of $\mathrm{IV}_{2}$. Finally, the eluate was collected in a $0.5 \mathrm{~mL}$ amber glass vial that was sealed and stored refrigerated at $-18^{\circ} \mathrm{C}$ until analysis by GC-MS.

\subsection{Method Validation}

The analytical performance of the proposed LLE-SPE/GC-MS method was evaluated in terms of linear range, sensitivity, selectivity, precision and accuracy. Linearity was assessed in uncontaminated samples of whole cow's milk and butter that were spiked with variable concentrations of PAHs.

The sensitivity of the proposed method was evaluated in terms of the limits of detection (LODs), which were calculated as the signal-to-noise ratios for 3 selected ions, and ranged from 1 to $100 \mathrm{ng} / \mathrm{kg}$ for milk and from 2 to $200 \mathrm{ng} / \mathrm{kg}$ for butter. The limits of quantification (LOQs) were calculated as 3.3 times the corresponding LODs and taken to be the lower limits of the linear ranges.

Precision was evaluated as the relative standard deviation (RSD) for 12 individual samples spiked with 500, 1000 and $2000 \mathrm{ng} / \mathrm{kg}$ (milk, yogurt, cheese, custard, cream and milkshakes) or 1000, 1500 and $3000 \mathrm{ng} / \mathrm{kg}$ (butter and margarine) on the same day (within-day RSD) or 3 consecutive days (between-day RSD). Finally, the analyte recoveries were evaluated in samples spiked with three different concentrations of PAHs (500, 1000 and $2000 \mathrm{ng} / \mathrm{kg}$ (milk, yogurt, cheese, custard, cream and milkshakes) or 1000, 1500 and $3000 \mathrm{ng} / \mathrm{kg}$ (butter and margarine) for analysis in triplicate $(n=3)$.

\section{Results and Discussion}

\subsection{Optimization of the Sample Treatment}

The high complexity of milk and dairy products requires careful optimization of each variable influencing analytical performance. Milk and dairy products contain variable proportions of fat (0.3-82\%) and protein (0.6-24\%) that can be removed in different ways to avoid matrix effects and to isolate the analytes [33]. Often, the procedure of choice involves a saponification pretreatment in combination with LLE and followed by SPE $[11,12,16,17]$. In this work, we initially used saponification with $\mathrm{NaOH}$ in methanol in combination with LLE and SPE. The results, however, were poor. Recently, our research group succeeded in determining the PAHs in edible oils using a $(9: 1 v / v)$ DMF: $\mathrm{H}_{2} \mathrm{O}$ mixture as the extractant [3]. This led us to use a $10 \mathrm{~mL}$ volume of the previous mixture to extract PAHs from dairy products (a $1 \mathrm{~g}$ sample was spiked with a $1000 \mathrm{ng} / \mathrm{kg}$ concentration of each analyte). Although the results were somewhat better than with saponification, the PAH recoveries 
were far from quantitative. Tests with different extraction mixtures containing $6 \mathrm{~mL}$ of DMF- $\mathrm{H}_{2} \mathrm{O}$ solution and $4 \mathrm{~mL}$ of $\mathrm{EtOH}, \mathrm{MeOH}$ or $n$-hexane revealed that the ethanolic mixture provided recoveries 5 times higher than the others, possibly because ethanol denatured proteins and caused them to precipitate, thereby facilitating the extraction of PAHs.

Extraction efficiency is typically related to the volume of organic solvent used. In this work, we established the optimum volume by spiking milk, yogurt, milkshake, cream, custard and cheese samples with a fixed analyte concentration (500 ng PAH $/ \mathrm{kg}$ ) for extraction with variable volumes (1-10 mL) of (9:1 v/v) DMF: $\mathrm{H}_{2} \mathrm{O}$ mixed with a fixed volume $(4 \mathrm{~mL})$ of $\mathrm{EtOH}$ for treatment as described in Section 2.3. The extraction yield increased with increasing volumes of DMF: $\mathrm{H}_{2} \mathrm{O}$ up to $6 \mathrm{~mL}$, above which it levelled off. The influence of the ethanol volume was examined by using a fixed volume $(6 \mathrm{~mL})$ of $(9: 1 \mathrm{v} / \mathrm{v})$ DMF: $\mathrm{H}_{2} \mathrm{O}$ and variable volumes of alcohol $(1-10 \mathrm{~mL})$. As can be seen in Figure 2, the PAH extraction efficiency peaked at EtOH volumes from 3 to $5 \mathrm{~mL}$. However, using too much ethanol compromised the isolation and dilution of PAHs in water with DFM: $\mathrm{H}_{2} \mathrm{O}$ as the extractant [34], whereas using too little detracted from protein precipitation, so a trade-off must be made. The optimum combination for a $1 \mathrm{~g}$ sample of the milk and dairy products-butter and margarine excepted - was found to be $6 \mathrm{~mL}$ of $(9: 1 v / v)$ DMF: $\mathrm{H}_{2} \mathrm{O}$ and $4 \mathrm{~mL}$ of EtOH. Because butter and margarine both contained greater amounts of fat, they had to be used in smaller amounts $(0.5 \mathrm{~g}$ instead of $1 \mathrm{~g})$, spiked with a $1500 \mathrm{ng} / \mathrm{kg}$ PAH concentration and treated with $6 \mathrm{~mL}$ of $(9: 1 v / v)$ DMF: $\mathrm{H}_{2} \mathrm{O}$ in combination with $5 \mathrm{~mL}$ of solvent (methanol, ethanol or $n$-hexane) as described in Section 2.3. The best results were obtained with DMF: $\mathrm{H}_{2} \mathrm{O}-n$-hexane, which provided near-quantitative $\mathrm{PAH}$ recoveries. On the other hand, methanol and ethanol provided highly cloudy extracts after centrifugation and extraction yields as low as $30 \%$ as a result. The influence of the proportion of $n$-hexane on the PAH extraction efficiency was examined by using volumes of 1-10 mL. As can be seen from Figure 3, the efficiency peaked at 4-6 $\mathrm{mL}$ and volumes above $6 \mathrm{~mL}$ decreased efficiency as a result of $n$-hexane interacting preferentially with non-polar PAHs and altering the coefficient of partition in the DMF: $\mathrm{H}_{2} \mathrm{O}$ mixture. We, thus, chose to use a mixture containing $6 \mathrm{~mL}$ of (9:1 v/v) DMF: $\mathrm{H}_{2} \mathrm{O}$ and $5 \mathrm{~mL}$ of $n$-hexane to extract PAHs from $0.5 \mathrm{~g}$ samples of margarine and butter.

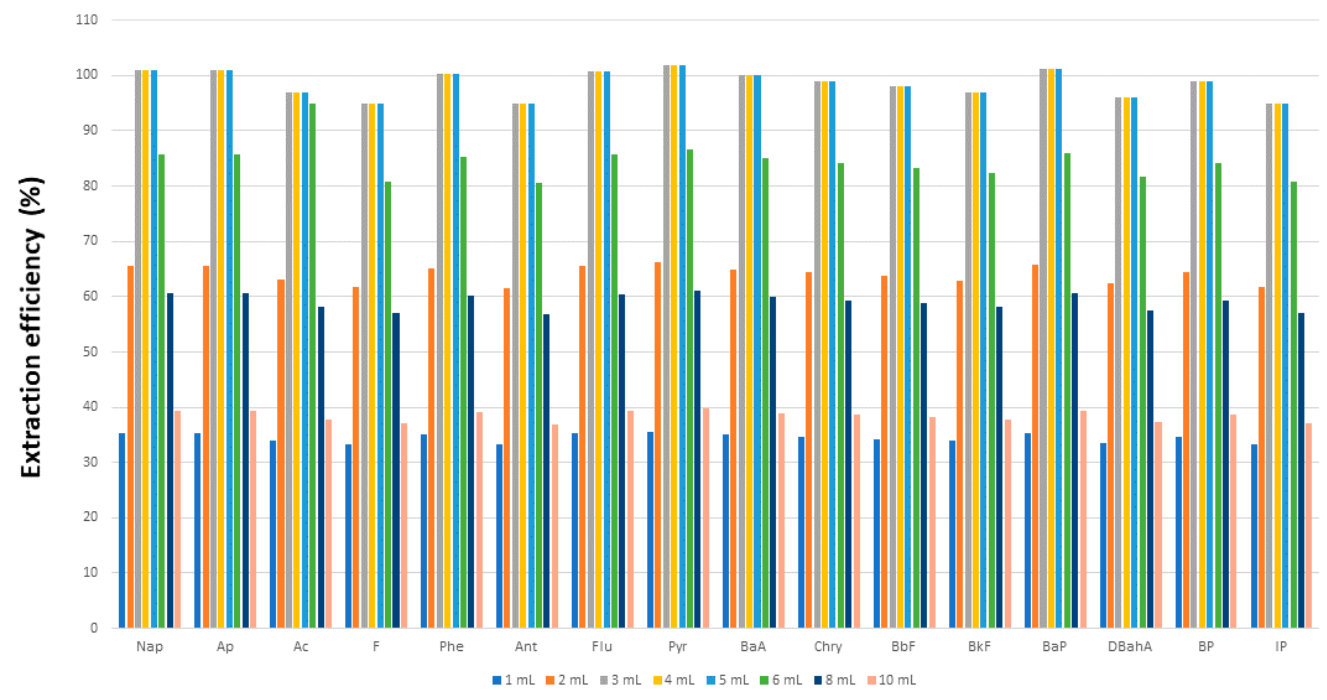

Figure 2. Influence of the volume of ethanol on the extraction of polycyclic aromatic hydrocarbons from dairy products.

The influence of centrifugation-related variables (time, temperature and speed) was examined using $1 \mathrm{~g}$ amounts for all milk and dairy products except butter and margarine $(0.5 \mathrm{~g})$ and following the $\mathrm{PAH}$ extraction procedure described in the previous paragraph. The temperature, centrifugation speed and time ranges studied were $0-10{ }^{\circ} \mathrm{C}, 430-2150 \mathrm{~g}$ 
and 1-30 min, and the optimum obtained values were $4{ }^{\circ} \mathrm{C}, 2150 \times g(5000 \mathrm{rpm})$ and $15 \mathrm{~min}$, respectively.

Performance in the SPE step was crucial, with to the goal of ensuring that the analytes would be fully isolated from their matrices with little or no interference. The SPE-LLE combination is widely used to extract analytes $[10-12,16,17,27]$. In this work, LLE extracts were cleaned up and preconcentrated by SPE. Various sorbents, including reversed-phase silica with octadecyl groups (RP-C18), Amberlites (XAD-2 anXAD-4), Oasis HLB and LiChrolut EN, were preliminarily used to remove interferents in the aqueous layer from LLE and preconcentrate PAHs. For this purpose, the aqueous layer from the preparation of milk and dairy products was passed through an SPE column (Figure S1, Supplementary Information) packed with $60 \mathrm{mg}$ of sorbent. The best results were obtained with RP-C18. Then, acetonitrile, methanol, ethanol, acetone, ethyl acetate and 2-propanol were tested as eluents and 2-propanol was found to be the most efficient in eluting retained PAHs from the sorbent column. The influence of the volume needed for complete elution of the PAHs was examined over the range of 50-500 $\mu \mathrm{L}$, using different loops placed in the second injection valve ( $\mathrm{IV}_{2}$ in Figure S1, Supplementary Information). The desorption efficiency increased with increasing injected volumes up to $350 \mu \mathrm{L}$ and then decreased because of the dilution of desorbed analytes. An injection volume of eluent of $350 \mu \mathrm{L}$ was, thus, selected as optimal.

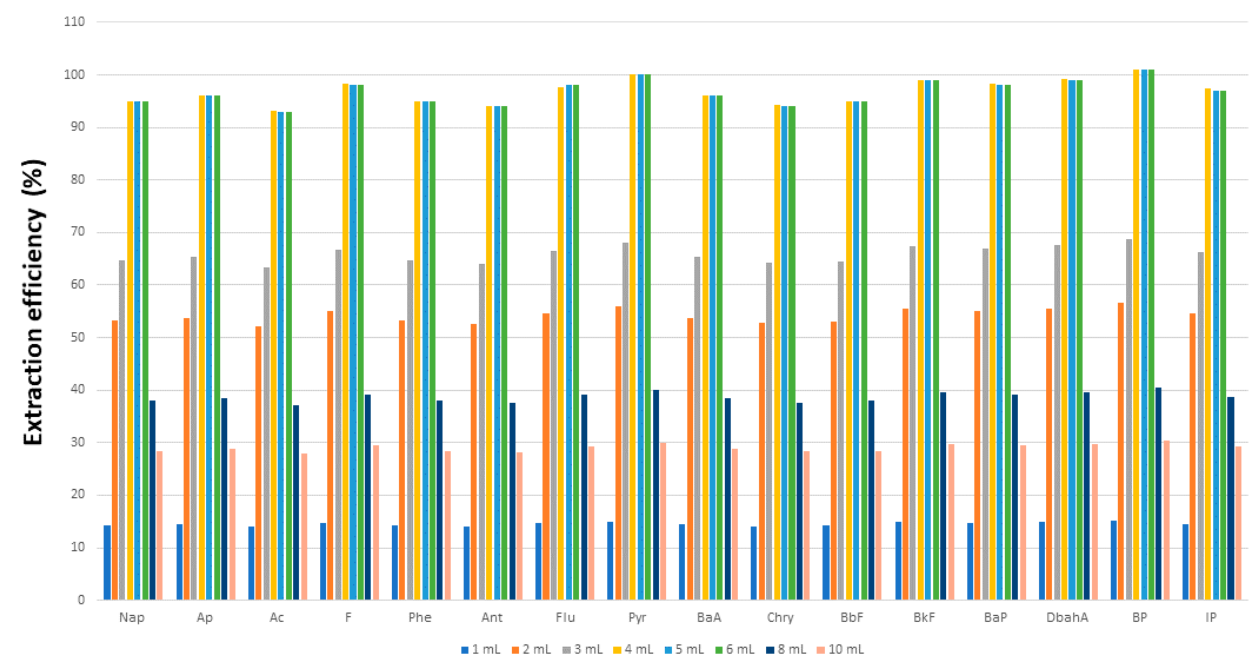

Figure 3. Influence of the volume of $n$-hexane on the extraction of polycyclic aromatic hydrocarbons from butter and margarine.

As seen in previous studies, PAH sorption onto RP-C18 can be altered by the presence of ethanol [35]. This led us to examine the effect by passing $50 \mathrm{~mL}$ volumes of aqueous samples containing variable proportions of ethanol (5-50\% v/v) and a $100 \mathrm{ng} / \mathrm{L}$ concentration of each PAH through the SPE column. The analyte elution was maximal at ethanol proportions below $20 \%$, so we used $8 \%$ in the aqueous samples so as not to exceed that limit and detract from SPE efficiency as a result. Finally, the influence of the breakthrough volume of the RP-C18 sorbent column was examined by using aqueous solutions containing $6 \mathrm{~mL}$ of $(9: 1 \mathrm{v} / \mathrm{v}) \mathrm{DMF}: \mathrm{H}_{2} \mathrm{O}$ and $4 \mathrm{~mL}$ of ethanol plus a fixed amount of PAHs $(5 \mathrm{ng})$ in $50-500 \mathrm{~mL}$. A sorption efficiency of ca. $100 \%$ was obtained with aqueous volumes up to $250 \mathrm{~mL}$.

\subsection{Analytical Performance}

With milk samples $(1 \mathrm{~g})$, the response of the method was linear over the range $4-20,000 \mathrm{ng} / \mathrm{kg}$ and the correlation coefficients $\left(r^{2}\right)$ were always higher than 0.993 . For butter $(0.5 \mathrm{~g})$, the linear range was $7-40,000 \mathrm{ng} / \mathrm{kg}$ and the correlation coefficients were similar to those for the milk samples. Table 2 and Table S1 (Supplementary Information) list the 
analytical figures of merit for all types of samples and, by way of example, Figure 4 shows a typical chromatogram for a whole cow's milk sample used to contrast the calibration curves.

Within-day RSDs were 5.0-10.2\% and between-day RSDs were 6.9-11.3\% (Table 2). Matrix effects (MEs) were evaluated by comparing the slopes of matrix-matched calibration curves with those of external standard calibration curves using the following equation: $\mathrm{ME}=(($ slope of matrix-matched curve/slope of in-solvent curve $)-1) \times 100$ [36]. As can be seen from Table 3, MEs ranged from 1 to $20 \%$ and were, thus, "soft" (i.e., the sample extraction/cleanup procedure was efficient enough to avoid matrix effects on the determination of PAHs). The recoveries ranged from 80 to 107\% (Table 3).

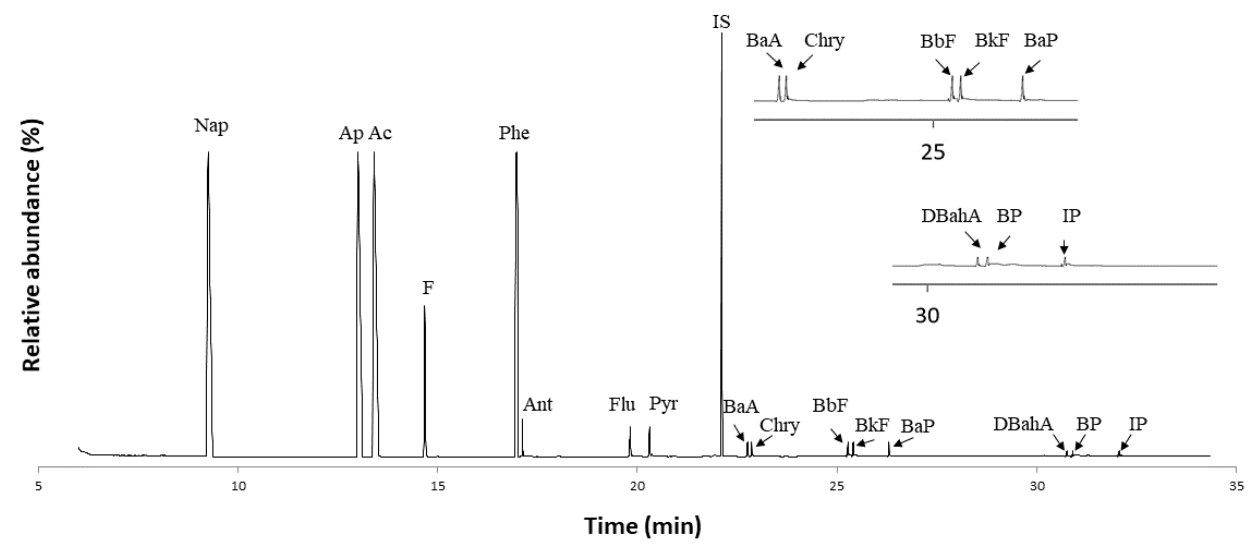

Figure 4. GC-MS chromatograms in the SIM mode for $1 \mathrm{~g}$ of whole cow's milk spiked with a $500 \mathrm{ng} / \mathrm{kg}$ concentration of each PAH. For peak assignments, see Table 2. IS, internal standard.

\subsection{Analysis of Real Samples}

The proposed method was used to determine the EPA's 16 priority PAHs in 11 milk samples (viz., whole, semi-skimmed and skimmed cow's milk, whole goat's milk and whole sheep's milk) and 19 dairy products (yogurt, cream, custard, cheese, milkshakes, butter and margarine). Each sample was analyzed in triplicate with an intervening blank. In each run, $1 \mathrm{~g}$ of sample ( $0.5 \mathrm{~g}$ for butter and margarine) was subjected to the procedure described in Section 2.4. As can be seen in Table 4, three samples (whole cow's milk, butter and margarine) contained none of the PAHs at levels above the limit of quantification of the proposed method; however, all others contained at least one, which testifies to the ubiquity of PAHs in industrial food products.

As can be also seen in Table 4, Nap was the most frequent PAH, at concentrations from 260 to $1900 \mathrm{ng} / \mathrm{kg}$ and, especially, in margarine, butter, custard and yogurt. Chung et al. (2010) studied the presence of sixteen PAHs in milk samples from Taiwan and found Nap in all samples, at concentrations from 67,000 to 310,000 ng/L [10]. They detected additional contaminants, such as Ap, Ac, F, Flu and Phe, albeit at low concentrations. More recently, Pluta-Kubica et al. (2020) found smoked cheeses to contain 16 PAHs, with Nap as the most concentrated $(20,000-1,200,000 \mathrm{ng} / \mathrm{kg})$ [28]. By contrast, Shariarifar et al. (2020) found this $\mathrm{PAH}$ at much lower levels (20-40 ng/kg) in milk and milk powder [19].

Acenaphthene was present in 10 samples, at concentrations from $7.1 \mathrm{ng} / \mathrm{kg}$ in semiskimmed milk to $510 \mathrm{ng} / \mathrm{kg}$ in butter. Two of the butter samples contained higher Ac concentrations than all others. This PAH was also found in yogurt, at levels from 650 to $1850 \mathrm{ng} / \mathrm{kg}$, and especially in yogurt with a high fat content (3.9\%) [29]. Gul et al. (2015) previously found Ac at high concentrations (110-3060 ng/kg) in cheese from Turkey [16]. 
Table 3. Results obtained in the recovery and matrix effect studies of the different types of milk and dairy product samples.

\begin{tabular}{|c|c|c|c|c|c|c|c|c|}
\hline & \multicolumn{8}{|c|}{ Recoveries $(\% \pm \text { SD. } n=3)^{\mathrm{a}}$} \\
\hline & Milk & Yogurt & Butter & Cheese & Custard & Cream & Milkshake & Margarine \\
\hline Naphthalene & $101 \pm 8$ & $100 \pm 9$ & $95 \pm 8$ & $99 \pm 9$ & $98 \pm 9$ & $99 \pm 9$ & $100 \pm 10$ & $96 \pm 9$ \\
\hline Acenaphthylene & $101 \pm 8$ & $105 \pm 8$ & $92 \pm 8$ & $107 \pm 10$ & $99 \pm 9$ & $97 \pm 8$ & $97 \pm 10$ & $105 \pm 9$ \\
\hline Acenaphthene & $82 \pm 8$ & $106 \pm 10$ & $93 \pm 10$ & $104 \pm 10$ & $89 \pm 8$ & $93 \pm 8$ & $100 \pm 9$ & $106 \pm 10$ \\
\hline Fluorene & $91 \pm 6$ & $107 \pm 10$ & $98 \pm 10$ & $97 \pm 9$ & $101 \pm 8$ & $105 \pm 10$ & $91 \pm 2$ & $107 \pm 9$ \\
\hline Phenanthrene & $100 \pm 9$ & $104 \pm 9$ & $93 \pm 9$ & $101 \pm 10$ & $89 \pm 7$ & $99 \pm 10$ & $95 \pm 9$ & $104 \pm 10$ \\
\hline Anthracene & $95 \pm 8$ & $101 \pm 9$ & $88 \pm 8$ & $96 \pm 10$ & $105 \pm 10$ & $87 \pm 8$ & $102 \pm 11$ & $101 \pm 11$ \\
\hline Fluoranthene & $101 \pm 3$ & $94 \pm 8$ & $98 \pm 8$ & $96 \pm 9$ & $100 \pm 11$ & $93 \pm 9$ & $97 \pm 10$ & $94 \pm 9$ \\
\hline Pyrene & $102 \pm 10$ & $94 \pm 8$ & $104 \pm 9$ & $87 \pm 8$ & $99 \pm 10$ & $100 \pm 11$ & $105 \pm 10$ & $95 \pm 9$ \\
\hline Benzo(a)anthracene & $106 \pm 10$ & $97 \pm 9$ & $85 \pm 8$ & $86 \pm 8$ & $105 \pm 9$ & $89 \pm 8$ & $99 \pm 11$ & $106 \pm 10$ \\
\hline Chrysene & $105 \pm 8$ & $82 \pm 6$ & $94 \pm 10$ & $87 \pm 8$ & $99 \pm 10$ & $102 \pm 6$ & $101 \pm 9$ & $82 \pm 8$ \\
\hline Benzo(b)fluoranthene & $94 \pm 6$ & $106 \pm 9$ & $95 \pm 10$ & $83 \pm 7$ & $100 \pm 10$ & $97 \pm 8$ & $98 \pm 10$ & $106 \pm 10$ \\
\hline Benzo(k)fluoranthene & $97 \pm 9$ & $93 \pm 8$ & $104 \pm 10$ & $102 \pm 9$ & $105 \pm 5$ & $96 \pm 9$ & $103 \pm 10$ & $93 \pm 9$ \\
\hline Benzo(a)pyrene & $101 \pm 9$ & $85 \pm 6$ & $98 \pm 10$ & $83 \pm 8$ & $99 \pm 9$ & $106 \pm 10$ & $89 \pm 8$ & $85 \pm 8$ \\
\hline Dibenzo[a,h]anthracene & $87 \pm 8$ & $93 \pm 8$ & $99 \pm 10$ & $86 \pm 7$ & $102 \pm 10$ & $105 \pm 11$ & $99 \pm 10$ & $93 \pm 8$ \\
\hline Benzo[g,h,i]perylene & $99 \pm 9$ & $90 \pm 7$ & $106 \pm 9$ & $86 \pm 7$ & $103 \pm 8$ & $99 \pm 10$ & $94 \pm 9$ & $90 \pm 9$ \\
\hline Indeno[1,2,3-cd]pyrene & $80 \pm 6$ & $100 \pm 10$ & $97 \pm 9$ & $95 \pm 9$ & $99 \pm 9$ & $100 \pm 10$ & $101 \pm 9$ & $100 \pm 10$ \\
\hline \multicolumn{9}{|c|}{ Matrix Effect (\%) $b$} \\
\hline & Milk & Yogurt & Butter & Cheese & Custard & Cream & Milkshakes & Margarine \\
\hline Naphthalene & $1.02(2 \%)$ & $\begin{array}{c}0.86 \\
(-14 \%)\end{array}$ & $0.92(-8 \%)$ & $0.99(-1 \%)$ & $\begin{array}{c}0.91 \\
(-9 \%)\end{array}$ & $0.91(-9 \%)$ & $1.02(2 \%)$ & $1.03(3 \%)$ \\
\hline Acenaphthylene & $1.10(10 \%)$ & $0.96(-4 \%)$ & $0.94(-6 \%)$ & $1.03(3 \%)$ & $\begin{array}{c}0.93 \\
(-7 \%)\end{array}$ & $0.99(-1 \%)$ & $0.96(-4 \%)$ & $1.06(6 \%)$ \\
\hline Acenaphthene & $1.09(9 \%)$ & $0.91(-9 \%)$ & $1.03(3 \%)$ & $1.06(6 \%)$ & $\begin{array}{c}0.85 \\
(-15 \%)\end{array}$ & $\begin{array}{c}0.86 \\
(-14 \%)\end{array}$ & $1.06(6 \%)$ & $0.93(-7 \%)$ \\
\hline Fluorene & $1.10(10 \%)$ & $0.99(-1 \%)$ & $\begin{array}{c}0.85 \\
(-15 \%)\end{array}$ & $\begin{array}{c}0.90 \\
(-10 \%)\end{array}$ & $1.06(6 \%)$ & $1.06(6 \%)$ & $0.99(-1 \%)$ & $1.03(3 \%)$ \\
\hline Phenanthrene & $1.03(3 \%)$ & $1.03(3 \%)$ & $\begin{array}{c}0.88 \\
(-12 \%)\end{array}$ & $0.92(-8 \%)$ & $1.06(6 \%)$ & $0.93(-7 \%)$ & $\begin{array}{c}0.90 \\
(-10 \%)\end{array}$ & $1.12(12 \%)$ \\
\hline Anthracene & $1.06(6 \%)$ & $1.06(6 \%)$ & $\begin{array}{c}0.90 \\
(-10 \%)\end{array}$ & $\begin{array}{c}0.81 \\
(-19 \%)\end{array}$ & $1.03(3 \%)$ & $\begin{array}{c}0.90 \\
(-10 \%)\end{array}$ & $1.03(3 \%)$ & $0.90(-10 \%)$ \\
\hline Fluoranthene & $0.91(-9 \%)$ & $0.93(-7 \%)$ & $\begin{array}{c}0.84 \\
(-16 \%)\end{array}$ & $\begin{array}{c}0.90 \\
(-10 \%)\end{array}$ & $1.03(3 \%)$ & $0.97(-3 \%)$ & $0.99(-1 \%)$ & $1.10(10 \%)$ \\
\hline Pyrene & $0.97(-3 \%)$ & $1.14(14 \%)$ & $1.14(14 \%)$ & $\begin{array}{c}0.82 \\
(-18 \%)\end{array}$ & $\begin{array}{c}0.97 \\
(-3 \%)\end{array}$ & $1.03(3 \%)$ & $1.03(3 \%)$ & $0.99(-1 \%)$ \\
\hline Benzo(a)anthracene & $1.03(3 \%)$ & $1.12(12 \%)$ & $1.04(4 \%)$ & $\begin{array}{c}0.82 \\
(-18 \%)\end{array}$ & $\begin{array}{c}0.90 \\
(-10 \%)\end{array}$ & $0.93(-7 \%)$ & $0.92(-8 \%)$ & $1.06(6 \%)$ \\
\hline Chrysene & $1.03(3 \%)$ & $0.95(-5 \%)$ & $0.96(-4 \%)$ & $\begin{array}{c}0.83 \\
(-17 \%)\end{array}$ & $1.03(3 \%)$ & $1.07(7 \%)$ & $1.06(6 \%)$ & $0.93(-7 \%)$ \\
\hline Benzo(b)fluoranthene & $1.05(5 \%)$ & $1.02(2 \%)$ & $\begin{array}{c}0.81 \\
(-19 \%)\end{array}$ & $\begin{array}{c}0.82 \\
(-18 \%)\end{array}$ & $\begin{array}{c}1.14 \\
(14 \%)\end{array}$ & $0.91(-9 \%)$ & $0.93(-7 \%)$ & $0.88(-12 \%)$ \\
\hline Benzo(k)fluoranthene & $1.03(3 \%)$ & $1.04(4 \%)$ & $0.98(-2 \%)$ & $\begin{array}{c}0.84 \\
(-16 \%)\end{array}$ & $1.04(4 \%)$ & $0.99(-1 \%)$ & $1.03(3 \%)$ & $1.04(4 \%)$ \\
\hline Benzo(a)pyrene & $1.09(9 \%)$ & $0.93(-7 \%)$ & $0.94(-6 \%)$ & $\begin{array}{c}0.90 \\
(-10 \%)\end{array}$ & $\begin{array}{c}0.93 \\
(-7 \%)\end{array}$ & $1.03(3 \%)$ & $\begin{array}{c}0.82 \\
(-18 \%)\end{array}$ & $1.06(6 \%)$ \\
\hline Dibenzo[a,h]anthracene & $1.06(6 \%)$ & $1.07(7 \%)$ & $0.93(-7 \%)$ & $\begin{array}{c}0.82 \\
(-18 \%)\end{array}$ & $1.03(3 \%)$ & $1.06(6 \%)$ & $\begin{array}{c}0.83 \\
(-17 \%)\end{array}$ & $1.14(14 \%)$ \\
\hline Benzo[g,h,i]perylene & $1.05(5 \%)$ & $1.16(16 \%)$ & $1.03(3 \%)$ & $1.06(6 \%)$ & $1.05(5 \%)$ & $0.97(-3 \%)$ & $\begin{array}{c}0.82 \\
(-18 \%)\end{array}$ & $0.93(-7 \%)$ \\
\hline Indeno[1,2,3-cd]pyrene & $\begin{array}{c}0.86 \\
(-14 \%)\end{array}$ & $1.19(19 \%)$ & $\begin{array}{c}0.86 \\
(-14 \%)\end{array}$ & $1.06(6 \%)$ & $\begin{array}{c}0.99 \\
(-1 \%)\end{array}$ & $1.06(6 \%)$ & $1.02(2 \%)$ & $1.06(6 \%)$ \\
\hline
\end{tabular}

a Percent recoveries $(\% \pm \mathrm{SD}, n=3)$ of PAHs spiked to milk and dairy product samples $(500 \mathrm{ng} / \mathrm{kg}$, except for butter and margarine, which were $1000 \mathrm{ng} / \mathrm{kg}$ ). ${ }^{\mathrm{b}}$ Matrix effects are expressed as the ratio between the calibration curve slope in matrix and the calibration curve slope in solvent. The result of the following operation is included in parentheses: ((calibration curve slope in matrix/calibration curve slope in solvent) -1$) \times 100$.

Fluorene was detected in 5 samples, at $30 \mathrm{ng} / \mathrm{kg}$ in sheep's milk and levels from 44 to $150 \mathrm{ng} / \mathrm{kg}$ in two types of cheese. One of the margarine samples contained as much as $520 \mathrm{ng} / \mathrm{kg}$ of this PAH. Sun et al. (2020) analyzed milk from 9 different countries (China, Ireland, Australia, Poland, Germany, France, Holland, Slovenia and New Zealand) and found them to contain $\mathrm{F}$ at concentrations from 100 to $880 \mathrm{ng} / \mathrm{kg}$, and at especially high levels in some samples from China [26]. Fasano et al. (2016) studied cheeses from Italy, 
Czech Republic, Poland and Spain and found them to contain F at levels from 17,000 to $77,000 \mathrm{ng} / \mathrm{kg}$ [12].

Table 4. Polycyclic aromatic hydrocarbons (mean values \pm standard deviation, $\mathrm{ng} / \mathrm{kg}$ ) found in various types of milk samples and dairy products $(n=3)$.

\begin{tabular}{|c|c|c|c|c|c|c|c|c|}
\hline Sample ${ }^{a}$ & Compounds & $\begin{array}{l}\text { Concentration } \\
\text { Found (ng/kg) }\end{array}$ & Sample ${ }^{a}$ & Compounds & $\begin{array}{c}\text { Concentration } \\
\text { Found } \\
(\mathrm{ng} / \mathrm{kg})\end{array}$ & Sample ${ }^{a}$ & Compounds & $\begin{array}{l}\text { Concentration } \\
\text { Found (ng/kg) }\end{array}$ \\
\hline $\begin{array}{c}\text { Skimmed } \\
\text { cow's milk } \\
1 \\
(0.3 \% / 3.3 \%)\end{array}$ & $\begin{array}{l}\text { Naphthalene } \\
\text { Acenaphthene } \\
\Sigma \text { PAH }\end{array}$ & $\begin{aligned} 580 & \pm 50 \\
50 & \pm 5 \\
630 & \pm 50\end{aligned}$ & $\begin{array}{c}\text { Whole } \\
\text { sheep's } \\
\text { milk } \\
(6.5 \% / 5.4 \%)\end{array}$ & $\begin{array}{l}\text { Acenaphthene } \\
\text { Fluorene } \\
\Sigma \text { PAH }\end{array}$ & $\begin{array}{l}17 \pm 2 \\
30 \pm 3 \\
47 \pm 4\end{array}$ & $\begin{array}{c}\text { Custard } 3 \\
(3.9 \% / 3.4 \%)\end{array}$ & Naphthalene & $1400 \pm 100$ \\
\hline $\begin{array}{c}\text { Skimmed } \\
\text { cow's milk } 2 \\
(0.3 \% / 3.3 \%)\end{array}$ & Naphthalene & $620 \pm 60$ & $\begin{array}{c}\text { Yoghurt } \\
\text { cow's 1 } \\
(2.6 \% / 3.9 \%)\end{array}$ & $\begin{array}{l}\text { Naphthalene } \\
\text { Acenaphthene } \\
\Sigma \mathrm{PAH}\end{array}$ & $\begin{array}{c}860 \pm 80 \\
51 \pm 5 \\
911 \pm 80\end{array}$ & $\begin{array}{l}\text { Cheese } 1 \\
(12.1 \% / 10.9 \%)\end{array}$ & Naphthalene & $490 \pm 40$ \\
\hline $\begin{array}{c}\text { Skimmed } \\
\text { cow's milk } 3 \\
(0.3 \% / 3.3 \%)\end{array}$ & Naphthalene & $800 \pm 70$ & $\begin{array}{c}\text { Yoghurt } \\
\text { cow's 2 } \\
(3.0 \% / 3.5 \%)\end{array}$ & $\begin{array}{l}\text { Naphthalene } \\
\text { Acenaphthene } \\
\text { इPAH }\end{array}$ & $\begin{aligned} 1500 & \pm 100 \\
35 & \pm 3 \\
1535 & \pm 100\end{aligned}$ & $\begin{array}{l}\text { Cheese } 2 \\
(13.1 \% / 12.9 \%)\end{array}$ & $\begin{array}{l}\text { Naphthalene } \\
\text { Acenaphthene } \\
\text { Fluorene } \\
\text { Phenanthrene } \\
\text { इPAH }\end{array}$ & $\begin{array}{c}900 \pm 80 \\
50 \pm 5 \\
44 \pm 4 \\
88 \pm 8 \\
1082 \pm 80\end{array}$ \\
\hline $\begin{array}{c}\text { Semi- } \\
\text { skimmed } \\
\text { cow's milk } \\
1 \\
(1.6 \% / 4.9 \%)\end{array}$ & $\begin{array}{l}\text { Naphthalene } \\
\text { Acenaphthene } \\
\Sigma \text { PAH }\end{array}$ & $\begin{array}{c}560 \pm 50 \\
7.1 \pm 0.6 \\
567.1 \pm 50\end{array}$ & $\begin{array}{c}\text { Yoghurt } \\
\text { cow's } 3 \\
(2.6 \% / 3.9 \%)\end{array}$ & $\begin{array}{l}\text { Naphthalene } \\
\text { Acenaphthene } \\
\Sigma \text { PAH }\end{array}$ & $\begin{aligned} 1100 & \pm 100 \\
35 & \pm 3 \\
1135 & \pm 100\end{aligned}$ & $\begin{array}{c}\text { Cheese } 3 \\
(12.9 \% / 10.1 \%)\end{array}$ & Fluorene & $150 \pm 10$ \\
\hline $\begin{array}{c}\text { Semi- } \\
\text { skimmed } \\
\text { cow's milk2 } \\
(1.6 \% / 4.9 \%)\end{array}$ & Naphthalene & $530 \pm 40$ & $\begin{array}{l}\text { Milkshake } 1 \\
(1.0 \% / 1.6 \%)\end{array}$ & Naphthalene & $580 \pm 50$ & $\begin{array}{c}\text { Butter } \\
(82.0 \% / 0.7 \%)\end{array}$ & $\begin{array}{l}\text { Naphthalene } \\
\text { Acenaphthene } \\
\Sigma \text { PAH }\end{array}$ & $\begin{aligned} 1000 & \pm 100 \\
300 & \pm 30 \\
1300 & \pm 100\end{aligned}$ \\
\hline $\begin{array}{c}\text { Semi- } \\
\text { skimmed } \\
\text { cow's milk2 } \\
(1.6 \% / 4.9 \%)\end{array}$ & Naphthalene & $570 \pm 50$ & $\begin{array}{l}\text { Milkshake } 2 \\
(1.0 \% / 1.6 \%)\end{array}$ & Naphthalene & $260 \pm 20$ & $\begin{array}{c}\text { Butter } \\
(81.0 \% / 0.5 \%)\end{array}$ & $\begin{array}{l}\text { Naphthalene } \\
\text { Acenaphthene } \\
\Sigma \text { PAH }\end{array}$ & $\begin{array}{l}440 \pm 40 \\
510 \pm 50 \\
950 \pm 60\end{array}$ \\
\hline $\begin{array}{c}\text { Whole } \\
\text { cow's milk } \\
1 \\
(3.6 \% / 3.2 \%)\end{array}$ & Naphthalene & $380 \pm 30$ & $\begin{array}{c}\text { Cream } 1 \\
(18.0 \% / 2.4 \%)\end{array}$ & Naphthalene & $330 \pm 30$ & $\begin{array}{c}\text { Butter } \\
(82.2 \% / 0.5 \%)\end{array}$ & $\mathrm{nq}^{\mathrm{b}}$ & \\
\hline $\begin{array}{c}\text { Whole } \\
\text { cow's milk } 2 \\
(3.6 \% / 3.2 \%)\end{array}$ & Naphthalene & $520 \pm 40$ & $\begin{array}{c}\text { Cream } 2 \\
(18.1 \% / 2.5 \%)\end{array}$ & Naphthalene & $290 \pm 30$ & $\begin{array}{c}\text { Margarine } \\
(60.0 \% / 0.5 \%)\end{array}$ & $\begin{array}{l}\text { Naphthalene } \\
\text { Fluorene } \\
\Sigma \text { PAH }\end{array}$ & $\begin{array}{c}1200 \pm 100 \\
520 \pm 50 \\
1720 \pm 110\end{array}$ \\
\hline $\begin{array}{c}\text { Whole } \\
\text { cow's milk } 3 \\
(3.6 \% / 3.2 \%)\end{array}$ & $\mathrm{nq}^{\mathrm{b}}$ & & $\begin{array}{c}\text { Custard } 1 \\
(2.9 \% / 3.4 \%)\end{array}$ & Naphthalene & $960 \pm 90$ & $\begin{array}{c}\text { Margarine } \\
(60.0 \% / 0.5 \%)\end{array}$ & $\begin{array}{l}\text { Naphthalene } \\
\text { Fluorene } \\
\Sigma \mathrm{PAH}\end{array}$ & $\begin{array}{c}1900 \pm 200 \\
220 \pm 20 \\
2120 \pm 200\end{array}$ \\
\hline $\begin{array}{c}\text { Whole } \\
\text { goat's milk } \\
(3.9 \% / 3.4 \%)\end{array}$ & $\begin{array}{l}\text { Naphthalene } \\
\text { Acenaphthene } \\
\text { इPAH }\end{array}$ & $\begin{aligned} 550 & \pm 50 \\
23 & \pm 2 \\
573 & \pm 50\end{aligned}$ & $\begin{array}{c}\text { Custard } 2 \\
(2.4 \% / 2.3 \%)\end{array}$ & Naphthalene & $780 \pm 70$ & $\begin{array}{c}\text { Margarine } \\
(60.5 \% / 0.5 \%)\end{array}$ & $\mathrm{nq}^{\mathrm{b}}$ & \\
\hline
\end{tabular}

a (\% fat content/ protein content). Samples of milk or dairy products are of different brands. ${ }^{\mathrm{b}}$ nq: PAHs concentration < LOQ $\Sigma \mathrm{PAH}$ includes the sum of all PAH.

Finally, phenanthrene was only detected, at $88 \mathrm{ng} / \mathrm{kg}$, in one cheese sample here. Other light PAHs were also detected in some samples but never at levels above the LOQs of the proposed method. As can be seen from Table 4, the PAH concentrations found were never exceedingly high. In fact, the combined concentration of PAHs ranged from $47 \mathrm{ng} / \mathrm{kg}$ in the least contaminated sample (whole sheep's milk) to $2120 \mathrm{ng} / \mathrm{kg}$ in one of margarine. Moreover, none of the samples contained $\mathrm{BaP}$, which is one of the most hazardous PAHs according to the U.S. EPA and the EU's Commission [13]. 


\section{Conclusions}

A total of sixteen PAHs deemed to be priority pollutants by the EPA were determined in milk and dairy products using an LLE-SPE/GC-MS method for the extraction, cleanup, detection and quantification of the analytes free from interferences from the sample matrix. The precision, linearity, recoveries and limits of detection afforded by the method make it an effective choice for determining the target analytes in milk and dairy samples. In fact, the method is highly sensitive, with limits of detection of 1-200 $\mathrm{ng} / \mathrm{kg}$ and, thus, similar to those obtained by Lee et al. (2015) using greater amounts of sample (10 g) [11] but somewhat less so for some analytes than the method of Shariatifar et al. (2020), whish used $5 \mathrm{~g}$ of sample and is only applicable to milk and milk powder (Table 1) [19].

The proposed method was successfully used to analyze a wide variety of milk and dairy products, including whole, semi-skimmed and skimmed cow's milk, goat's milk, sheep's milk, yogurt, milkshakes, cream, custard, cheese, butter and margarine, for PAHs. Only three samples contained no PAH at concentrations above the limit of quantitation of the method. All others contained at least one but none contained more than four. Moreover, all detected PAHs were of the lighter type (Nap, Ap, F and Phe). In any case, none of the four PAHs whose maximum levels in infant formula and follow-on milk are limited by Regulation (EU) No 835/2011 (BaP, BaA, BbF and Chry) were detected in any sample [13]. These findings offer an efficient and timely tool for evaluating the public risk associated with the presence of PAHs in milk and dairy products.

Supplementary Materials: The following supporting information can be downloaded at: https: / / www.mdpi.com/article/10.3390/foods11050713/s1, Figure S1: Continuous-flow system for the solid-phase extraction of PAHs from dairy products; Table S1: Regression equation and quantification limit of the determination of PAHs in milk and dairy product by the proposed method.

Author Contributions: Conceptualization, L.P.C.; investigation, L.P.C., A.J.R. and E.B.; methodology, A.J.R. and E.B.; validation, L.P.C., A.J.R. and E.B.; writing-original draft preparation, L.P.C. and A.J.R.; writing-review and editing, E.B.; project administration and funding acquisition, E.B.; supervision, E.B. All authors have read and agreed to the published version of the manuscript.

Funding: This research was funded by Consejería de Economía, Conocimiento, Empresas y Universidad, Regional Government of Andalucía, Spain (Project Ref. PY2018-1211) and partially supported by EU FEDER funds and the Research Programme of the University of Jaen (Plan 2019-2020).

Institutional Review Board Statement: Not applicable.

Informed Consent Statement: Not applicable.

Data Availability Statement: Not applicable.

Acknowledgments: The technical and human support provided by CICT of University of Jaén (UJA, MINECO, Junta de Andalucía, FEDER) is gratefully acknowledged.

Conflicts of Interest: The authors declare no conflict of interest.

\section{References}

1. Górska-Warsewicz, H.; Rejman, K.; Laskowski, W.; Czeczotko, M. Milk and dairy products and their nutritional contribution to the average Polish diet. Nutrients 2019, 11, 1771. [CrossRef]

2. Raza, N.; Kim, K.H. Quantification techniques for important environmental contaminants in milk and dairy products. TrAC-Trends Anal. Chem. 2018, 98, 79-94. [CrossRef]

3. Rascón, A.J.; Azzouz, A.; Ballesteros, E. Multiresidue determination of polycyclic aromatic hydrocarbons in edible oils by liquidliquid extraction-solid-phase extraction-gas chromatography-mass spectrometry. Food Control 2018, 94, 268-275. [CrossRef]

4. Sirot, V.; Rivière, G.; Leconte, S.; Vin, K.; Traore, T.; Jean, J.; Carne, G.; Gorecki, S.; Veyrand, B.; Marchand, P.; et al. French infant total diet study: Dietary exposure to heat-induced compounds (acrylamide, furan and polycyclic aromatic hydrocarbons) and associated health risks. Food Chem. Toxicol. 2019, 130, 308-316. [CrossRef] [PubMed]

5. Sun, K.; Song, Y.; He, F.; Jing, M.; Tang, J.; Liu, R. A review of human and animals exposure to polycyclic aromatic hydrocarbons: Health risk and adverse effects, photo-induced toxicity and regulating effect of microplastics. Sci. Total Environ. $2021,773,145403$. [CrossRef] [PubMed] 
6. Acharya, N.; Gautam, B.; Subbiah, S.; Rogge, M.M.; Anderson, T.A.; Gao, W. Polycyclic aromatic hydrocarbons in breast milk of obese vs normal women: Infant exposure and risk assessment. Sci. Total Environ. 2019, 668, 658-667. [CrossRef]

7. Martin-Tornero, E.; Luque-Uría, A.; Durán-Merás, I.; Espinosa-Mansilla, A. A novel analytical methodology for the determination of hydroxy polycyclic aromatic hydrocarbons in breast and cow milk samples. J. Chromatogr. B 2020, 1136, 121912. [CrossRef]

8. Grova, N.; Monteau, F.; Le Bizec, B.; Feidt, C.; Andre, F.; Rychen, G. Determination of phenanthrene and hydroxyphenanthrenes in various biological matrices at trace levels using gas chromatography-mass spectrometry. J. Anal. Toxicol. 2005, 29, 175-181. [CrossRef]

9. Amirdivani, S.; Khorshidian, N.; Ghobadi Dana, M.; Mohammadi, R.; Mortazavian, A.M.; Quiterio de Souza, S.L.; Barbosa Rocha, H.; Raices, R. Polycyclic aromatic hydrocarbons in milk and dairy products. Int. J. Dairy Technol. 2019, 72, 120-131. [CrossRef]

10. Chung, T.L.; Liao, C.J.; Chen, M.F. Comparison of liquid-liquid extraction and solid-phase extraction for the determination of polycyclic aromatic hydrocarbons in the milk of Taiwan. J. Taiwan Inst. Chem. Eng. 2010, 41, 178-183. [CrossRef]

11. Lee, S.Y.; Lee, J.Y.; Shin, H.S. Evaluation of chemical analysis method and determination of polycyclic aromatic hydrocarbons content from seafood and dairy products. Toxicol. Res. 2015, 31, 265-271. [CrossRef] [PubMed]

12. Fasano, E.; Yebra-Pimentel, I.; Martínez-Carballo, E.; Simal-Gándara, J. Profiling, distribution and levels of carcinogenic polycyclic aromatic hydrocarbons in traditional smoked plant and animal foods. Food Control 2016, 59, 581-590. [CrossRef]

13. European Commission. Commission Regulation (UE) No 835/2011 of 19 August 2011 ameding Regulation (EC) No 1881/2006 as regards maximum levels for polycyclic aromatic hydrocarbons in foodstuffs. Off. J. Eur. Comm. 2011, L215, 4-8.

14. United States Environmental Protection Agency (USEPA). Appendix A to 40 CFR, Part 423-426; EPA: Washington, DC, USA, 2012. Available online: https://www3.epa.gov/region1/npdes/permits/generic/prioritypollutants.pdf (accessed on 11 February 2022).

15. IARC. Some Non-Heterocyclic Polycyclic Aromatic Hydrocarbons and Some Related Exposures. IARC Monographs on the Evaluation of Carcinogenic Risks Humans; IARC: Lyon, France, 2010; Volume 92, pp. 1-853. Available online: http:/ / publications.iarc.fr/110 (accessed on 11 February 2022).

16. Gul, O.; Dervisoglu, M.; Mortas, M.; Aydemir, O.; Ilhan, E.; Aksehir, K. Evaluation of polycyclic aromatic hydrocarbons in Circassian cheese by high-performance liquid chromatography with fluorescence detection. J. Food Compos. Anal. 2015, 37, 82-86. [CrossRef]

17. Naccari, C.; Cristani, M.; Giofrè, F.; Ferrante, M.; Siracusa, L.; Trombetta, D. PAHs concentration in heat-treated milk samples. Food Res. Int. 2011, 44, 716-724. [CrossRef]

18. Santonicola, S.; Albrizio, S.; Murru, N.; Ferrante, M.C.; Mercogliano, R. Study on the occurrence of polycyclic aromatic hydrocarbons in milk and meat/fish based baby food available in Italy. Chemosphere 2017, 184, 467-472. [CrossRef]

19. Shariatifar, N.; Dadgar, M.; Fakhri, Y.; Shahsavari, S.; Moazzen, M.; Ahmadloo, M.; Kiani, A.; Aeenehvand, S.; Nazmara, S.; Mousavi Khanegah, A. Levels of polycyclic aromatic hydrocarbons in milk and milk powder samples and their likely risk assessment in Iranian population. J. Food Compos. Anal. 2020, 85, 103331. [CrossRef]

20. Zhang, S.; Niu, H.; Zhang, Y.; Liu, J.; Shi, Y.; Zhang, X.; Cai, Y. Biocompatible phosphatidylcholine bilayer coated on magnetic nanoparticles and their application in the extraction of several polycyclic aromatic hydrocarbons from environmental water and milk samples. J. Chromatogr. A 2012, 1238, 38-45. [CrossRef]

21. Lin, W.; Wei, S.; Jiang, R.; Zhu, F.; Ouyang, G. Calibration of the complex matrix effects on the sampling of polycyclic aromatic hydrocarbons in milk samples using solid phase microextraction. Anal. Chim. Acta 2016, 933, 117-123. [CrossRef]

22. Pang, J.; Yuan, D.; Huang, X. On-line combining monolith-based in-tube solid phase microextraction and high-performance liquid chromatography- fluorescence detection for the sensitive monitoring of polycyclic aromatic hydrocarbons in complex samples. J. Chromatogr. A 2018, 1571, 29-37. [CrossRef]

23. Aguinaga, N.; Campillo, N.; Viñas, P.; Hernández-Córdoba, M. Determination of 16 polycyclic aromatic hydrocarbons in milk and related products using solid-phase microextraction coupled to gas chromatography-mass spectrometry. Anal. Chim. Acta 2007, 596, 285-290. [CrossRef] [PubMed]

24. Wang, M.; Cheng, C.; Liu, C.; Yang, Y. Hollow fiber supported ionic liquids liquid-phase micro-extraction followed by highperformance liquid chromatography for the determination of polycyclic aromatic hydrocarbons in milk samples. J. Chromatogr. Sci. 2018, 56, 74-80. [CrossRef] [PubMed]

25. Luzardo, O.P.; Zumbado, M.; Boada, L.D. Concentrations of polycyclic aromatic hydrocarbons and organohalogenated contaminants in selected foodstuffs from Spanish Market basket: Estimated intake by the population from Spain. J. Food. Agric. Environ. 2013, 11, 437-443.

26. Sun, Y.; Yan, K.; Wu, S.; Gong, G. Occurrence, Spatial distribution and impact factors of 16 polycyclic aromatic hydrocarbons in milks from nine countries. Food Control 2020, 113, 107197. [CrossRef]

27. Iwegbue, C.M.A.; Bassey, F.I. Concentrations and health hazards of polycyclic aromatic hydrocarbons in selected commercial brands of milk. J. Food Meas. Charact. 2013, 7, 177-184. [CrossRef]

28. Pluta-Kubica, A.; Filipczak-Fiutak, M.; Domagała, J.; Duda, I.; Migdał, W. Contamination of traditionally smoked cheeses with polycyclic aromatic hydrocarbons and biogenic amines. Food Control 2020, 112, 107115. [CrossRef]

29. Battisti, C.; Girelli, A.M.; Tarola, A.M. Polycyclic aromatic hydrocarbons (PAHs) in yogurt samples. Food Addit. Contam. Part B Surveill. 2015, 8, 50-55. [CrossRef] [PubMed] 
30. Ciecierska, M.; Obiedziński, M.W. Polycyclic Aromatic hydrocarbons in infant formulae, follow-on formulae and baby foods available in the Polish market. Food Control 2010, 21, 1166-1172. [CrossRef]

31. Kacmaz, S. Polycyclic aromatic hydrocarbons in retail Turkish yogurts. Qual. Assur. Saf. Crops Foods 2019, 11, 361-367. [CrossRef]

32. Kishikawa, N.; Wada, M.; Kuroda, N.; Akiyama, S.; Nakashima, K. Determination of polycyclic aromatic hydrocarbons in milk samples by high-performance liquid chromatography with fluorescence detection. J. Chromatogr. B 2003, 789, 257-264. [CrossRef]

33. Muñoz Hornillos, M.; Yoldi Bienzobas, G. Leche y derivados. In Alimentos Composición y Propiedades; Astiasarán Anchía, I., Martínez Hernández, J.A., Eds.; McGraw-Hill-Interamericana de España, S.A.U.: Madrid, Spain, 2003; pp. 69-108.

34. Zougagh, M.; Redigolo, H.; Ríos, A.; Valcárcel, M. Screening and confirmation of PAHs in vegetable oil samples by use of supercritical fluid extraction in conjunction with liquid chromatography and fluorimetric detection. Anal. Chim. Acta 2004, 525, 265-271. [CrossRef]

35. Rascón, A.J.; Azzouz, A.; Ballesteros, E. Use of semi-automated continuous solid-phase extraction and gas chromatography-mass spectrometry for the determination of polycyclic aromatic hydrocarbons in alcoholic and non-alcoholic drinks from Andalucía (Spain). J. Sci. Food Agric. 2019, 99, 1117-1125. [CrossRef] [PubMed]

36. Matuszewski, B.K.; Constanzer, M.L.; Chavez-Eng, C.M. Strategies for the assessment of matrix effect in quantitative bioanalytical methods based on HPLC-MS/MS. Anal. Chem. 2003, 75, 3019-3030. [CrossRef] [PubMed] 